\title{
ORIGIN AND EVOLUTION OF CULTIVATED CUCURBITS
}

\author{
ORIGEM E EVOLUÇÃO DE CUCURBITÁCEAS CULTIVADAS
}

\author{
Dilson Antônio Bisognin ${ }^{1}$
}

\section{- REVISÃO BIBLIOGRÁFICA -}

\section{SUMMARY}

Cucurbits (Cucurbitaceae) are among the most important plant families supplying humans with edible products and useful fibers. Plants of this family are very similar in above ground development, but they have high genetic diversity for fruit shape and other fruit characteristics, resulting in a variety of uses. The objective of this review was to discuss the origin and evolution of the most important cultivated cucurbits. Understanding the evolutionary history and domestication process increase the possibility for better exploiting the genetic diversity for cultivar development. The domestication selection in cucurbits was for shape, less bitter flesh, larger and fewer seeds, and larger fruit size, resulting in high genetic diversity within and among cultivated species. This variation can be associated with the wide range of uses that require different shape, size and a constant ratio between fruit length and fruit diameter. The discussion of the breeding history indicates how artificial selection could speed up changes in fruit characteristics to attend specific uses and increase adaptation to a variety of environmental conditions in which cucurbits are growing worldwide. Although interspecific hybridization has been employed in cucurbit breeding more than in any other family, there is still a high potential for increasing its application for germplasm and cultivar development.

Key words: Cucurbita spp., Cucumis spp., Citrullus lanatus, Lagenaria siceraria, Luffa spp.

\section{RESUMO}

As cucurbitáceas (Cucurbitaceae) são uma das mais importantes famílias de plantas utilizadas para produção de alimentos e fibras. Apesar de a parte aérea das plantas desta família ser muito similar em seu desenvolvimento, grande variabilidade genética tem sido mantida para formato e outras características de fruto, o que aumenta o seu potencial de uso. $O$ objetivo desta revisão foi discutir a origem e a evolução das cucurbitáceas cultivadas. A história da evolução e o conhecimento das alterações ocorridas durante este processo podem facilitar a utilização e a exploração da variabilidade genética para o desenvolvimento de germoplasma e de novas cultivares. A seleção durante o processo de domesticação foi para formato de fruto, redução de gosto amargo na polpa, aumento de tamanho e redução do número de sementes $e$ aumento do tamanho de frutos. Esta seleção permitiu a manutenção de grande variabilidade genética entre e dentro das espécies cultivadas, a qual está associada a uma diversidade de usos que requer diferentes formatos, tamanhos e uma constante relação entre comprimento e diâmetro de fruto. A discussão da história do melhoramento genético de cucurbitáceas mostra como a seleção artificial pode aumentar o ganho de seleção para caraterísticas de fruto, para atender usos específicos, e para adaptabilidade às mais diversas regiões do mundo. Apesar de a hibridação interespecífica ter sido amplamente utilizada no melhoramento genético de cucurbitáceas, ainda existe um grande potencial para aumentar seu uso afim de desenvolver germoplasma e novas cultivares.

Palavras chave: Cucurbita spp., Cucumis ssp. Citrullus lanatus, Lagenaria siceraria, Luffa spp.

\section{INTRODUCTION}

Cucurbits belong to the family Cucurbitaceae and consist of about 118 genera and 825 species, according to the last taxonomic treatment of JEFFREY (1990). Cucurbits are present

\footnotetext{
${ }^{1}$ Agronomy Engineer Ph.D., Professor of the Fitotecnia Department, Center of Rural Sciences, Federal University of Santa Maria, 97105-900, Santa Maria - RS, BRAZIL. E-mail:dilsonb@ccr.ufsm.br.
} 
in both the New and Old World and are among the most important plant families that supply human with edible products and useful fibers. Cucurbits are divided into five sub-families: Fevilleae, Melothrieae, Cucurbitaceae, Sicyoideae, and Cyclanthereae. The most important cultivated genera are Cucurbita L., Cucumis L., Citrullus L., Lagenaria L., and Luffa L., found in the sub-family Cucurbitaceae, and Sechium L., found in the sub-family Sicyoideae (WHITAKER \& DAVIS, 1962). This review focuses on the most important species in those genera, which are Cucurbita, squash and pumpkins (C. maxima Duch., C. moschata (Duch. ex Lam.) Duch. \& Poir, C. pepo L., or C. argyrosperma Hubersyn. C. mixta Pang.) and fig-leaf gourd $\boldsymbol{C}$. ficifolia Bouché.); in the genus Cucumis, cucumber (C. sativus L.) and melon $\boldsymbol{C}$. melo L.); in the genus Citrullus, watermelon ( $\boldsymbol{C}$. lanatus (Thunb.) Mat. \& Nak.); in the genus Lagenaria, bottlegourd (L. siceraria (Mol.) Standl.); in the genus Luffa, angled loofah (L. acutangula (L.) Roxb.), smooth loofah (L. aegyptiaca Mill. syn. L. cylindrica (L.) Roem.) or loofah (Luffa ssp.); and in the genus Sechium, chayote (S. edule (Jacq.) Swartz) (Table 1).

Among the cucurbits, watermelon is the most popular in the world. The United Nations' Food and Agriculture Organization (FAO) estimated an average annual area of cultivation of 2.5 million ha and an annual production of 46.6 million tons of watermelon fruits between 1996 and 1998. Next in total world production were cucumber, melon, squash and pumpkins. In terms of countries, China is the leading producer of major cucurbit crops followed by Turkey, Iran and Ukraine. In the Americas, Argentina is an important producer of squash and pumpkins and the United States is an important producer of cucumber, melon and watermelon (FAO, 1998). The most important cucurbits in Brazil are squash, watermelon and melon, whose total production in 1995 was 535 million fruits harvested from an area of 206,000ha (IBGE, 1996).

Although cultivated cucurbits are very similar in above ground development and root habit, they are extremely diverse for fruit characteristics. Fruits are eaten when immature (summer squash) or mature (watermelon). Fruits can be baked (squash), pickled (cucumber), candied (watermelon), or consumed fresh in salads (cucumber) or dessert (melon). Also, seeds, flowers (squash and pumpkins) and roots (chayote) are consumed by humans. Cucurbits are also produced for other uses than food. Fruits (bottlegourd) are used for storage, drinking containers, bottles, utensils, smoking pipes, musical instruments, gourdcraft decoration, masks, floats for fish net, and other items. The fiber of a mature loofah fruit can be used as a sponge for personal hygiene, household cleaning and various other purposes, including filtration. Seeds or fruit parts of some cucurbits are reported to possess purgatives, emetics and antihelmintics properties due to the secondary metabolite cucurbitacin content (ROBINSON \& DECKER-WALTERS, 1997). Fruits and roots with high cucurbitacin content function as an insect attractant (e.g. cucumber beetle - Diabrotica ssp.) or as an insect repellent (e.g. honeybee - Apis mellifera L. and yellow jacket wasp -Vespula sp.) (CHAMBLISS \& JONES, 1966a). Ectopic application of cucurbitacin can function as a protectant against infection by Botrytis cinerea (BAR-NUN \& MAYER, 1990).

Therefore, cucurbits are among the largest and the most diverse plant families, have a large range of fruit characteristics, and are cultivated worldwide in a variety of environmental conditions. Cucurbits are associated with the origin of agriculture and human civilizations and are also among the first plant species to be domesticated in both the Old and the New World. The objective of this review was to discuss the origin and evolution of the most important cultivated cucurbits.

\section{ORIGIN, EARLY SPREAD EVOLUTIONARY HYSTORY}

The bitter flavor of cucurbits is caused by cucurbitacin that is associated with the co-evolution of cucumber beetle. Cucurbitacin is a toxic secondary compound present only in Cucurbitaceae. Cucurbitacin is a tetracyclic terpenoid that arose to protect these plants from herbivores, functioning as repellent for most insect species (CHAMBLISS \& JONES, 1966b). Cucumber beetle developed an extraordinary detoxification mechanism that enabled these insects to grow, develop and reproduce on highly toxic level of cucurbitacins. These beetles are attracted to feed on bitter plant organs. Interestingly, eggs produced by these beetles have substantial quantities of cucurbitacins that protect them against ant predators (METCALF \& RHODES, 1990). One single dominant gene is responsible for the formation of bitter cucurbitacin compounds in Lagenaria, Cucumis, Cucurbita and Citrullus. Since cucurbitacin is attractive to cucumber beetle, resistance is achieved by selecting for reduced cucurbitacin content (ROBINSON et al., 1976).

\section{Squash and Pumpkins - Cucurbita ssp. \\ Cucurbita or yellow flowered cucurbit is} considered to be one of the most morphologicaly 
Table 1 - Latin and common names, diploid chromosome number and area of origin of the most important species of cultivated cucurbits.

\begin{tabular}{|c|c|c|c|}
\hline Latin name & Common name* & Chromosome & Area of origin \\
\hline & & number $(2 n)$ & \\
\hline Citrullus lanatus (Thunb.) Mat. \& Nak. & Watermelon & 22 & Africa and India \\
\hline Cucumis sativus $\mathrm{L}$. & Cucumber & 14 & India \\
\hline Cucumis melo L. & Melon & 24 & Africa \\
\hline Cucurbita ficifolia Bouché. & Fig-leaf gourd & 40 & Mexico, Central and South Americas \\
\hline $\begin{array}{l}\text { Cucurbita argyrosperma Huber. } \\
\text { syn. C. mixta Pang. }\end{array}$ & Winter squash & 40 & Mexico, Central America \\
\hline Cucurbita maxima Duch. & Winter squash, pumpkin & 40 & South America \\
\hline $\begin{array}{l}\text { Cucurbita moschata (Duch. ex. Lam.) } \\
\text { Duch. \& Poir. }\end{array}$ & Winter squash & 40 & Mexico, South America \\
\hline Cucurbita pepo L. & Summer squash, pumpkin, marrow & 40 & North and Central Americas \\
\hline Lagenaria siceraria (Mol.) Standl. & Porongo, white-flowered gourd & 22 & Africa \\
\hline $\begin{array}{l}\text { Luffa aegyptiaca Mill. } \\
\text { syn. L. cylindrica }(\mathrm{L} .) \text { Roem. }\end{array}$ & Smoth loofah & 26 & India \\
\hline Luffa acutangula (L.) Roxb. & Angled loofah & 26 & India \\
\hline Sechium edule (Jacq.) Swartz & Chayote & 24 & Mexico, Central America \\
\hline
\end{tabular}

* Most usual common names found in the literature.

variable genera in the entire plant kingdom (ROBINSON et $\boldsymbol{a l}$., 1976). The 22 wild and five cultivated species are extremely diverse in fruit color, size, and shape. The cultivated species are reproductively isolated from each other by genetic barriers and can be identified using morphological characteristics (WHITAKER \& BEMIS, 1964; WHITAKER \& BEMIS, 1975; NEE, 1990). The constant and relatively high chromosome number $(2 n=40)$ as well as the complex isozyme pattern suggest an allopolyploid origin for the genus (SINGH, 1979; KIRKPATRICK et al., 1985).

Archaeological records of the New World suggest that Cucurbita was one of the first plant to be domesticated (NEE, 1990). Cucurbita-corn-bean complex formed the nutritional basis for preColumbian civilizations in the Western Hemisphere (WHITAKER \& BEMIS, 1975). One of the first species to be domesticated in the New World was $\boldsymbol{C}$. pepo. Cultivation by the inhabitants of Guila Naquitz cave dated between 10,000 to 8,000 before present $(\mathrm{BP})$, predating corn and beans by more than 4,000 years (SMITH, 1997).

The origin and early spread of all Cucurbita species was in the Americas. Cucurbita ficifolia was the most widespread cultivated species with a native range in the mountains from Mexico to northern Chile and Argentina (WHITAKER \& BEMIS, 1975; WILSON et al., 1992). Cucurbita maxima was the only cultivated species with a native range restricted to South America, in the warm temperate areas of Uruguay and Argentina. Cucurbita moschata was native to the low lands of tropical and sub-tropical America (Mexico and South America), C. argyrosperma to the pacific coast ranging from Mexico to Nicaragua, and $\boldsymbol{C}$. pepo to the high elevations of Mexico and northern Central America (NEE, 1990; WILSON et al., 1992). Also, C. moshata was unique in being spread in two distinct native areas, a major one in Mexico and a minor one in the northern South America (WHITAKER \& BEMIS, 1975).

The cultivated species of Cucurbita can be divided into mesophytic annuals (C. maxima, $\boldsymbol{C}$. argyrosperma, $C$. moschata, and $C$. pepo) or mesophytic perennial (C. ficifolia) (WHITAKER \& BEMIS, 1964). Three species have defined ancestors. Cucurbita andreana Naud., a weedy species, is the ancestor of $\boldsymbol{C}$. maxima; $\boldsymbol{C}$. sororia Bailey is the ancestor of $\boldsymbol{C}$. argyrosperma (NEE, 1990); and C. fraterna Bailey and/or C. texana (Scheele) Gray are the possible ancestors of $\boldsymbol{C}$. pepo (DECKER, 1988; NEE, 1990). Allozyme analysis showed an independent domestication of $\boldsymbol{C}$. pepo in the eastern United States and in Mexico, from divergent populations of the original and respective wild progenitors $\boldsymbol{C}$. fraterna and $\boldsymbol{C}$. texana (DECKER-WALTERS, 1990). The high level of gene flow between $C$. texana and $C$. pepo in field experiments suggested a long-term of interspecific hybridizations and confirmed $\boldsymbol{C}$. texana as ancestor of $\boldsymbol{C}$. pepo (KIRKPATRICK \& WILSON, 1988). 
Genetic diversity studies indicated that cultivated species belong to different genetic groups. A dendrogram of 21 Cucurbita species constructed from data using 93 phenotypic characters grouped cultivated species in five different groups (WHITAKER \& BEMIS, 1975). Chloroplast DNA diversity analysis also placed cultivated species in different groups, being $\boldsymbol{C}$. pepo in two sub-groups: one with $\boldsymbol{C}$. texana and another with $\boldsymbol{C}$. fraterna (WILSON et al., 1992). Among cultivated species, C. moshata was the most variable and closely related species and nearest the common ancestor of the genus, because of the high interspecific compatibility (WHITAKER \& BEMIS, 1975). Isozyme study showed high allelic diversity in $C$. pepo and C. moschata. Cucurbita pepo shares a common ancestor with $\boldsymbol{C}$. moschata and $\boldsymbol{C}$. argyrosperma, but not with $\boldsymbol{C}$. maxima (DECKERWALTERS et al., 1990).

\section{Cucumber - Cucumis sativus}

According to a recent comprehensive biosystematic monograph of KIRKBRIDE (1993), the genus Cucumis includes 32 annual and perennial species divided in to two very distinct groups defined by geographic origin and chromosome number (African $2 n=24$ and Asiatic group $2 n=14$ chromosomes). The African group includes melon (C. melo) and the Asiatic group includes cucumber (C. sativus) and its probable ancestor $\boldsymbol{C}$. sativus var. hardwickii (Royle) or simply C. hardwickii (PERLTREVES \& GALUN, 1985). Studies based on isozymes, chloroplast DNA and restriction fragment length polymorphism supported the distinction between melon and cucumber (PERL-TREVES \& GALUN, 1985; PERL-TREVES et al., 1985).

There are two theories that attempt to explain the existence of a haploid chromosome number $n=7$ and a close relative with a haploid chromosome number $n=12$. The haploid chromosome number may have been increased to ( $n$ $=12)$ by fragmentation or reduced $(n=7)$ by fusion. Fusion is supported by the increased amount of heterochromatin content in $C$. sativus (RAMACHANDRAN \& NARAYAN, 1985) and by the presence of chromosomal alterations (karyotypic) in Cucumis speciation (SING \& ROY, 1974). Comparative genomics between $C$. melo and C. sativus may clarify the phylogeny of these species (DANIN-POLEG $\boldsymbol{e t}$ al., 2001).

Cucumber originated in India about 3,000 years ago and was soon cultivated in the South and East of the Himalayas, forming the Asiatic group (KROON et $\boldsymbol{a l}$., 1979; RAMACHANDRAN \& NARAYAN, 1985). From India, cucumber was brought to Greece and Italy and later to China. Records confirmed cucumber cultivation in France in the $9^{\text {th }}$ century, England in the $14^{\text {th }}$ century and in North America by the mid-16 ${ }^{\text {th }}$ century (SWIADER et al., 1992).

\section{Melon - Cucumis melo}

The African group (melon group) has 30 species divided into six subgroups (KIRKBRIDE, 1993). Melon and other $2 n=24$ species were originally distributed across a large part of Africa and Middle East up to Pakistan and South Arabia. However, some species also occurred in the Asiatic group range (KROON et al., 1979; RAMACHANDRAN \& NARAYAN, 1985). This is the case of $\boldsymbol{C}$. hystrix Chakr., which is the only $2 n=$ 24 native to Asia. This species is of particular interest because of morphological and biochemical characteristics similar to $\boldsymbol{C}$. sativus and chromosome number equal to $\boldsymbol{C}$. melo, indicating a possible bridge between the two species (CHEN \& ADELBERG, 2000).

Archeological remains indicated that melon was cultivated in Iran 5,000 BP. India, Iran, Afghanistan and China remain as areas of melon diversification (ROBINSON \& DECKERWALTERS, 1997). Ancient melon that was distributed throughout the Middle East and Asia originated the genetic diversity that exists in the area (ROBINSON \& DECKER-WALTERS, 1997). Melon was introduced in Central America in 1516, in Virginia in 1609, and in New York in 1629 (WARE \& McCOLLUM, 1980). Melon can be considered as the most highly developed types of ancient cultivated species and, through many changes, melon could get into those elite forms that exist today (MALLICK \& MASUI, 1986).

\section{Watermelon - Citrullus lanatus}

The genus Citrullus consists of eight species and sub-species. Watermelon, the only cultivated species of the genus, is a diploid with 22 chromosomes $(2 n=22)$ (MALLICK \& MASUI, 1986). The watermelon ancestor is the bitter-fruit form of C. vulgaris Schrader. (MOHR, 1986). Watermelon originated in Africa and India (MALLICK \& MASUI, 1986). Watermelon is an important crop in warmer parts of Russia and other parts of Asia Minor, the Near East, China and Japan. In the New World, cultivation began in Massachusetts as early as 1629 (MOHR, 1986). Watermelon was brought to America by Spanish and quickly became very popular crop (ROBINSON \& DECKER-WALTERS, 1997). 


\section{Bottlegourd - Lagenaria siceraria}

A total of six species have been recognized as belonging to the genus Lagenaria or white flowered gourds. One is the domesticated monoecious species $\boldsymbol{L}$. siceraria while five of them are wild perennial, dioecious forms from Africa and Madagascar. The basic haploid chromosome number in the genus is $11(2 n=22)$ (SING, 1990). Bottlegourd was domesticated in Asia and at the same time indigenous to Africa (WHITAKER \& DAVIS, 1962). Tropical Africa remains as the primary gene pool for this species (SING, 1990).

Bottlegourd was the most widely distributed plant in the world (HEISER, 1979) with a long history of use in both Old and New Worlds (ROBINSON \& DECKER-WALTERS, 1997). In the Old World, bottlegourd cultivation was traced back over 5,000 years BP (ROBINSON \& DECKER-WALTERS, 1997). Archeological evidences showed that bottlegourd was cultivated in North America in 10,000-7,500 years BP and in South America in 6,000-5,000 years BP. There is no secure argument that can be used to resolve the unusual bi-hemispheric distribution of bottlegourd. Experimental evidence suggested that the early spread from Africa to the New World could occur through oceanic drift (WHITAKER \& DAVIS, 1962). At the present time, it is cultivated throughout the tropical and subtropical regions of the world for food and useful gourds (WHITAKER \& DAVIS, 1962).

\section{Loofah - Luffa ssp.}

The genus $\mathbf{L u f f a}$ is comprised of seven species, four well-differentiated species from the Old World (L. echinata Roxb, L. acutangula, $L$. aegyptiaca, and L. graveolens Roxb.) and three species from the New World (L. quinquefida (Hook. \& Arn.) Seem., L. operculata (L.) Cogn., and $\boldsymbol{L}$. astorii Svens.) (HEISER \& SCHILLING, 1990). All species have 26 chromosomes $(2 n=26)$ (DUTT \& ROY, 1990; HEISER \& SCHILLING, 1990). The early spread of the genus $\boldsymbol{L u f f a}$ was in the New and Old World, but both cultivated species originated in India (HEISER \& SCHILLING, 1990).

Cytological and hybridization studies suggest a close relationship between the two cultivated species (L. aegyptiaca and L. acutangula) and their derivation from either L. graveolens or an unidentified common ancestor (DUTT \& ROY, 1990). While Old World species are well differentiated from each other and from the American species, the American species are rather similar to each other. Luffa aegyptiaca is the most extensively cultivated species (HEISER \& SCHILLING, 1990).

\section{Chayote - Sechium edule}

Chayote is the only cultivated Cucurbit in the sub-family Sicyoideae. Sechium was previously considered monotypic, but now includes as many as eight species (NEWSTROM, 1990). The cultivated chayote is diploid with 24 chromosomes $(2 n=24)$. This species and all their wild relatives were native to the New World (WHITAKER \& DAVIS, 1962). Chayote was domesticated in Mexico and Guatemala in pre-Columbian times either from wild forms of the species or from its closest relative $S$. compositum (Sm.) Jeffe. (NEWSTROM, 1990). After America colonization, chayote spread rapidly to all tropical areas of the New World and became a popular staple item in the diet for people of the Old World (WHITAKER \& DAVIS, 1962). Today, chayote is cultivated throughout tropical and subtropical regions of the world (NEWSTROM, 1990).

\section{CHANGES UNDER DOMESTICATION}

Cucurbita is prized for their edible seed, shell and rind. Selection for large seed may have resulted in large fruit. Immature fruit were selected for non-bitter flesh and mature fruit for non-bitter and starchy flesh and non-lignified rinds (PARIS, 1989). Domestication was characterized by the selection for shape, less bitter flesh, larger and fewer seeds, and larger fruit. Selection for non-bitter fruit was a key step in squash domestication. Seed was probably the first part used as food, since generally bitter fruit had non-bitter seeds (ROBINSON \& DECKER-WALTERS, 1997).

The domestication selection in other cucurbits was also for fruit characteristics. In cucumber, the spiny character and bitterness in fruit have decreased or disappeared (MALLICK \& MASUI, 1986). In watermelon, domestication selection was for fruit size and quality from wild progenitors with bitterness fruit (SINGH, 1990). In loofah, domestication changes were for more deeply furrowed, less bitter and larger fruit, reaching lengths of $50 \mathrm{~cm}$ (HEISER \& SCHILLING, 1990). There was a sex expression transition in cucumber and melon during domestication. In cucumber, the transition was from monoecious to gynoecious, which increased fruit maturity uniformity and early harvest yield (LOWER \& EDWARDS, 1986). In melon, a single dominant mutation changed the andromonoecious condition to pistillate (WHITAKER \& DAVIS, 1962). 
Cucurbits have one of the most variable and complex sex expression systems, which is regulated by both genetic and environmental factors. Sex expression has a direct effect on breeding and seed production. Most cucurbit species are monoecious and dioecious evolved more recently in the family. Sex expression is either controlled by a single gene (Cucurbita pepo) or two or more genes (Cucumis melo and $\boldsymbol{C}$. sativus) with three or more alleles for each gene (Luffa ssp.) (ROBINSON \& DECKER-WALTERS, 1997). Also, sex expression changes during plant development. NITSCH $\boldsymbol{e t} \boldsymbol{a l}$. (1952) found that squash plants initially were vegetative, changing to androecious and later to monoecious. Squash plants with only staminate flowers have also been identified. A very similar sex expression was found in cucumber, in which long days, high light intensity and high temperature induce androecious and opposite conditions induce gynoecious (SHIFRISS, 1961).

\section{BREEDING HISTORY}

Until approximately 60 years ago, Cucurbita cultivars were characterized by high genetic variability attributed in part to the tendency to outcross. Demand for uniformity and selection for earliness and fruit size, color, shape, and quality resulted in high homozygosity and true breeding cultivars. During the past 35 years, inbred lines have been used to develop hybrids, which were more uniform and homogeneous than previous open pollinated cultivars (PARIS, 1989). Interspecific hybrids between $\boldsymbol{C}$. maxima and $\boldsymbol{C}$. moschata were also developed to increase fruit quality. The most common interspecific hybrid is the cultivar 'Tetsukabuto' that is a cross between $C$. maxima cv. 'Delicious' and C. moshata cv. 'Kurokawa no. 2' using $\boldsymbol{C}$. maxima as the maternal parent (ROBINSON \& DECKER-WALTERS, 1997). This cross is male sterile requiring the use of a pollinator cultivar, which makes the production difficult and more expensive.

Cucurbita breeding programs have focused on some specific characteristics. A deep orange fruit color is more attractive in appearance and have higher concentration of pro-vitamin $\mathrm{A}$ (WHITAKER \& ROBINSON, 1986). Bush type plants, which have short internodes as a result of reduced biosynthesis of endogenous gibberillin, were developed in some species to improve crop management. Cucurbita pepo and C. maxima bush plants have more uniform growth and better response to high density planting compared to vine plants (LOY \& BRODERICK, 1990). In C. pepo, a single allele plus modifiers inhibit the formation of the seed coat. Naked seeds are tasty, tender and nutritious with high content of protein and oil (ROBINSON \& DECKER-WALTERS, 1997). More recently, parthenocarpic cultivars have become important. Normally, cucurbits depend on insect pollination for reproduction. However, parthenocarpic cultivars can be grown in greenhouses and in the field without staminate flowers and also increase fruit set under unfavorable pollination conditions (ROBINSON \& REINERS, 1999).

In cucumber breeding, a large range of methods can be used to improve disease resistance, yield, fruit appearance and other fruit quality characteristics, and sex expression (LOWER \& EDWARDS, 1986). Cultivar selection in United States began in the late 1880 s, with emphasis on fruit shape, color and adaptation, and choosing superior plants in heterogeneous populations (ROBINSON \& DECKER-WALTERS, 1997). Cucumber cultivars are usually classified according to their use as fresh market slices, pickles, or greenhouse cucumbers. Several fruit characteristics are considered in cultivar selection as shape, color, spine type (coarse or fine), spine color (white or black), fruit length/diameter ratio, skin thickness, and surface warts. Gynoecious hybrids (all machine harvest) replaced many of the monoecious types used for processing cucumbers, but for fresh market slices, both monoecious and gynoecious hybrids are available (SWIADER $\boldsymbol{e t}$ al., 1992).

The breeding history of melon in America dated back to the selection of the green flesh type cultivar 'Rocky Ford'. Selection for orange flesh cultivars began in the early 1900s. Disease resistant cultivars were developed in the 1930s and the first F1 hybrid was introduced in 1955, becoming the predominant type of melon cultivars (ROBINSON \& DECKER-WALTERS, 1997). Breeding for yield, disease resistance and fruit high density have been the most important goals in a melon breeding program (WHITAKER \& DAVIS, 1962).

The goals of watermelon breeding programs are yield and quality (fruit size for packaging as opposed to machine harvesting, color flesh, sweetness, flesh texture), earliness, dwarf habit, disease resistance, and development of F1 hybrid cultivars either diploids or seedless triploid (MOHR, 1986). The progeny of tetraploid (maternal parent) and diploid (paternal parent) crosses are seedless triploid (KIHARA, 1950). Triploid hybrids are highly sterile and fruits may have small empty seed coat or occasionally few seeds (ROBINSON \& DECKER-WALTERS, 1997). However, fruit set is 
dependant on pollination from a diploid plant, which makes production expensive and difficult (SHOEMAKER, 1992), since in a $1.5 \mathrm{~m}$ spacing between rows, one row of diploid pollinator needs to be added for every four rows of triploid hybrid (NESMITH \& DUVAL, 2001). Biotechnology has being used to solve specific breeding problems. The development of resistant cultivars to the most important aphid-transmitted viruses has been done through transgenic expression of virus coat protein in different cucurbit species (ARCE-OCHOA et al., 1995).

Bottlegourds are produced in the southern area of Brazil for cuia (container used to drink mate). Landrace varieties are monoecious or andromonoecious and still show high genetic diversity. Bottlegourd varieties are primarily identified based on fruit shape and WHITAKER \& DAVIS (1962) recognized 15 fruit shapes as just the most common ones. Fruit shape and size in bottlegourd is the most variable among cucurbits (HEISER, 1979) and is probable associated with the wide range of uses that require specific fruit characteristics. This high diversity is also reflected in the seed. Selection efforts are based on fruit characteristics such as shape, size and thickness. Fruit shape selection for cuia is based on measurements of the external diameter. Moderate heritability (0.36) was found for fruit shape based on individual fruit measurements explaining, in part, the high diversity among landrace varieties (BISOGNIN \& STORCK, 2000).

Interspecific crosses are widely used in cucurbits to transfer desirable characteristics from wild progenitors or related species to cultivated genotypes. Interspecific hybrids have been produced in Cucurbita, Cucumis, Citrullus, and Luffa . However, interspecific hybridization has only been successfully used for crop improvement in Cucurbita (ROBINSON \& DECKER-WALTERS, 1997), which includes the development of hybrid cultivars (C. maxima and $\boldsymbol{C}$. moshata). RHODES (1959) used Cucurbita lundelliana Bailey as a bridge to transfer certain desirable characters of one cultivated species to another, including tolerance to powdery mildew found in this species, and to form an interbreeding population or gene pool. Cucurbita moschata was also used as a bridge to transfer disease resistance (powdery mildew and cucumber mosaic virus), good fruit quality and insect resistance from $\boldsymbol{C}$. martinezii to $C$. pepo (WHITAKER \& ROBINSON, 1986). In Cucumis, African species carry many desirable characteristics, as disease resistance, not found in Asiatic species. However, strong barriers were found in crosses between annual and perennial Cucumis species (KROON et $\boldsymbol{a l} ., 1979$ ) and no viable seeds were obtained from any cross between African and Asiatic groups. Based on pollen tube behavior, $\boldsymbol{C}$. africanus L. and $\boldsymbol{C}$. melo appear to be the most promising male parents for crossing with $C$. sativus, but special pollination techniques and advanced embryo culture methods are necessary to overcome interspecific barriers in several crosses (KHO et al., 1980). The first successful and repeatable cross between African and Asiatic group was made by CHEN et al. (1997) by crossing $\boldsymbol{C}$. hystrix with $\boldsymbol{C}$. sativus. The parental species have different chromosome numbers resulting in a F1 hybrid $2 n=$ 19 ( $n=7$ from $C$. sativus and $n=12$ from $\boldsymbol{C}$. hystrix). The chromosome number of the hybrid was doubled $(2 n=4 x=38)$ and may be useful as a new crop as well as a bridging species for transferring genes between African and Asiatic groups (CHEN \& ADELBERG, 2000).

In summary, specific trends can be identified in cucurbit evolution and breeding. The domestication selection was for fruit shape, less bitter flesh, larger and fewer seeds, and larger fruit size. This resulted in maintaining high genetic diversity for fruit shape, size and texture within and among cultivated species. In cucurbit breeding, fruit shape is the most important characteristic. There is an appropriated ratio between fruit length and fruit diameter to attend each purpose. Edible fruits are characterized by thin rind and mature fruits for more developed rind, increasing fruit protection. Fruit size is another important characteristic and the most desired size might change depending on use or harvest system. Selection for non-bitter fruits and leaves, multiple insect and disease resistance, and earliness are also general breeding goals. More at species level, selection of gynoecious plants is used to ensure earliness and to facilitate hybrid seed production. The use of wide crosses is another important aspect in cucurbit breeding and many studies have been done to identify wild species that can be hybridized with cultivated ones to introgress disease resistance and other important characteristics. The identification of bridge species will increase the use of wild progenitors in breeding and facilitate gene introgression in those not close related species. There is a high potential for increasing the use of interspecific hybridization for germplasm and cultivar development.

\section{ACKNOWLEDGMENTS}

I would like to thank Dr. Samuel Hazen, Plant Research Laboratory and Dr. Jim Hankock, Department of 
Horticulture, Michigan State University, USA for their critical review of the manuscript.

\section{REFERENCES}

ARCE-OCHOA, J.P., DAINELLO, F., PIKE, L.M. Field performance comparison of two transgenic summer squash hybrids to their parental hybrid line. HortScience, v.30, n.3, p.492-493, 1995.

BAR-NUN, N., MAYER, A.M. Cucurbitacins protect cucumber tissue against infection by Botrytis cinerea . Phytochemistry, v.29, n.3, p.787-791, 1990 .

BISOGNIN, D.A., STORCK, L. Variance components and heritability estimation for fruit shape in bottlegourd Lagenaria siceraria (Mol.) Standl. Ciência Rural, v.30, n.4, p.593-597, 2000.

CHEN, J.F., STAUB, J.E., TASHIRO, Y., et al Successful interspecific hybridization between Cucumis sativus L. and C. hystrix Chakr. Euphytica, v.96, p.413-419, 1997.

CHEN, J.F., ADELBERG, J. Interspecific hybridization in Cucumis - progress, problems, and perspectives. HortScience, v.35, n.1, p.11-15, 2000.

CHAMBLISS, O.L., JONES, C.M. Cucurbitacins: specific insect attractants in Cucurbitaceae. Science, v.153, p.1392-1393, 1966 .

CHAMBLISS, O.L., JONES, C.M. Chemical and genetic basis for insect resistance in cucurbits. Amer Soc Hort Sci, v.89, p.394-405, 1966 b.

DANIN-POLEG, Y., REIS, N., BAUDRACCO-ARNAS, et al. Simple sequence repeats in Cucumis mapping and map merging. Genome, v.43, p.963-974, 2000.

DECKER, D.S. Origin(s), evolution, and systematics of Cucurbita pepo (Cucurbitaceae). Econ Bot, v.42, n.1, p.415, 1988.

DECKER-WALTERS, D.S. Evidence for multiple domestications of Cucurbita pepo. In: BATES, D.M., ROBINSON, R.W., JEFFREY, C. Biology and utilization of the Cucurbitaceae. Ithaca and London : Cornell University, 1990. p.96-101. $485 \mathrm{p}$.

DECKER-WALTERS, D.S., WALTERS, T.W., POSLUSZNY, U., et al. Genealogy and gene flow among annual and domesticated species of Cucurbita . C an J Bot, v.68, p.782$789,1990$.

DUTT, B., ROY, R.P. Cytogenetics of the old world species of Luffa. In: BATES, D.M., ROBINSON, R.W., JEFFREY, C. Biology and utilization of the Cucurbitaceae. Ithaca and London : Cornell University, 1990. p.134-140. 485p.

FAO. Production year book for 1998. Food and Agriculture Organization of the United Nations, Rome, 1998. v.52.

HEISER, C.B., SCHILLING, E.E. The genus Luffa: a problem in phytogeografy. In: BATES, D.M., ROBINSON, R.W., JEFFREY, C. Biology and utilization of the Cucurbitaceae. Ithaca and London : Cornell University, 1990. 120-133. $485 \mathrm{p}$.

HEISER, C.B. The gourd book. University of Oklahoma, 1979. 235p.
IBGE. Instituto Brasileiro de Geografia e Estatística. Censo Agropecuário 1995/1996. Rio de Janeiro, 1996. Ni.

JEFFREY, D. Appendix: An outline classification of the Cucurbitaceae. In: BATES, D.M., ROBINSON, R.W., JEFFREY, C. Biology and utilization of the Cucurbitaceae. Ithaca and London : Cornell University, 1990. p.449-463. 485p.

KHO, Y.O, DENNIJS, A.P.M., FRANKEN, J. Interspecific hybridization in Cucumis (L.). II. The crossability of species, an investigation of in vivo pollen tube growth and seed set. Euphytica, v.29, p.661-672, 1980.

KIHARA, H. Triploid watermelons. Proc Amer Soc Hort Sci, v.69, p.217-230, 1950.

KIRKBRIDE, J.H. Jr. Biosystematic monograph of the genus Cucumis (Cucurbitaceae). North Carolina : Parkway, Boone, 1993. 159p.

KIRKPATRICK, K.J., DECKER, D.S., WILSON, H.D. Allozyme differentiation in the Cucurbita pepo complex: $\boldsymbol{C}$. pepo var. medullosa vs. C. texana. Econ Bot, v.39, n.3, p.289-299, 1985.

KIRKPATRICK, K.J., WILSON, H.D. Interspecific gene flow in Cucurbita: C. texana vs. C. pepo. Amer J Bot, v.75, n.4, p.519-527, 1988.

KROON, G.H., CUSTERS, J.B.M., KHO, Y.O., et al. Interspecific hybridization in Cucumis (L.). I. Need for genetic variation, biosystematic relations and possibilities to overcome crossability barries. Euphytica, v.28, p.723-728, 1979.

LOWER, R.L., EDWARDS. M.D. Cucumber breeding. In: BASSETT, M.J. (Ed.). Breeding vegetable crops . Westport: Connecticut, Avi, 1986. p.173-207. 584p.

LOY, J.B., BRODERICK, C.E. Growth, assimilate partitioning, and productivity of bush and vine Cucurbita maxima. In: BATES, D.M., ROBINSON, R.W., JEFFREY, C. Biology and utilization of the Cucurbitaceae. Ithaca and London : Cornell University, 1990. p.436-447. 485p.

MALLICK, M.F.R., MASUI, M. Origin, distribution and taxonomy of melons. Scientia Horticulturae, v.28, p.252261,1986

METCALF, R.L., RHODES, A.M. Co-evolution of the Cucurbitaceae and Luperini (Coleoptera: Chrysomelideae): basic and apply aspect. In: BATES, D.M., ROBINSON, R.W., JEFFREY, C. Biology and utilization of the Cucurbitaceae. Ithaca and London : Cornell University, 1990. p.167-182. 485p.

MOHR, H.C. Watermelon breeding. In: BASSETT, M.J. (Ed.). Breeding vegetable crops. Westport, Connecticut : Avi, 1986. p.37-66. 584 p.

NEE, M. The domestication of Cucurbita (Cucurbitaceae). Econ Bot, v.44, n.3 (supplement), p.56-68, 1990.

NESMITH, D.S., DUVAL, J.R. Fruit set of triploid watermelons as a function of distance from a diploid pollinizer. HortScience, v.36, n.1, p.60-61, 2001. 
NEWSTROM, L.E. Origin and evolution of chayote, Sechium edule. In: BATES, D.M., ROBINSON, R.W., JEFFREY, C. Biology and utilization of the Cucurbitaceae. Ithaca and London : Cornell University, 1990. p.141-149. 485p.

NITSCH, J.P., KURTZ, E.B. Jr., LIVERMAN, J.L., et al The development of sex expression in cucurbit flowers. Amer $\mathbf{J}$ Bot, v.39, p.32-43, 1952.

PARIS, H.S. Historical records, origins, and development of the edible cultivar groups of C. pepo (Cucurbitaceae). Econ Bot, v.43, n.4, p.423-443, 1989.

PERL-TREVES, R., GALUN, E. The Cucumis plastome: physical map, intrageneric variation and phylogenetic relationships. Theor Appl Genet, v.71, p.417-429, 1985.

PERL-TREVES, R., ZAMIR, D., NAVOT, N., et al. Phylogeny of Cucumis based on isozyme variability and its comparison with plastome phylogeny. Theor Appl Genet, v.71, p.430436, 1985.

RAMACHANDRAN, C., NARAYAN, R.K.J. Chromosomal DNA variation in Cucumis. Theor Appl Genet, v.69, p.497502, 1985.

RHODES, A.M. Species hybridization and interspecific gene transfer in the genus Cucurbita. Amer Soc Hort Sci, v.74, p.546-551, 1959.

ROBINSON, R.W., D.S. DECKER-WALTERS. Cucurbits. New York Cab International, 1997. 226p. (Crop Production Science in Horticulture $\mathrm{n}^{\circ} .6$ ).

ROBINSON, R.W., MUNGER, H.M., WHITAKER, T.W., et al. Genes of Cucurbitaceae. HortScience, v.11, n.6, p.554-568, 1976.

ROBINSON, R.W., REINERS, S. Parthenocarpy in summer squash. HortScience, v.34, n.4, p.715-717, 1999.

SHIFRISS, O. Sex control in cucumbers. J Heredity, v.52, p.5$12,1961$.
SHOEMAKER, W.H. Melons, muskmelons, watermelons, and honeydews. In: SWIADER, J.M., WARE, G.W., McCOLLUM, J.P. Producing vegetable crops. Danville, Illinois : Interstate, 1992. p.361-380.

SINGH, A.K., ROY, R.P. Karyological studies in Cucumis (L.). Caryologia, v.27, n.2, p.153-160, 1974.

SINGH, A.K. Cucurbitaceae and polyploidy. Cytology, v.44, p.897-905, 1979.

SINGH, A.K. Cytogenetics and evolution in the Cucurbitaceae. In: BATES, D.M., ROBINSON, R.W., JEFFREY, C. Biology and utilization of the Cucurbitaceae. Ithaca and London : Cornell University, 1990. p.10-28. 485p.

SMITH, B.D. The initial domestication of C. pepo in the Anerucas 10,000 years ago. Science, v.276, p.932-934, 1997.

SWIADER, J.M., WARE, G.W., McCOLLUM, J.P. Producing vegetable crops. Danville, Illinois : Interstate, 1992. 626p.

WARE, G.W., McCOLLUM, J.P. Producing vegetable crops . Danville, Illinois : Interstate, 1980. 607p.

WHITAKER, T.W., BEMIS, W.P. Evolution in the genus Cucurbita . Evolution, v.18, p.553-559, 1964.

WHITAKER, T.W., BEMIS, W.P. Origin and evolution of the cultivated Cucurbita . Bull Torrey Bot Club, v.102, p.362368,1975 .

WHITAKER, T.W., DAVIS, G.N. Cucurbits: botany, cultivation and utilization. New York : Interscience, 1962. 250p.

WHITAKER, T.W., ROBINSON, R.W. Squash breeding. In: BASSETT, M.J. (Ed.). Breeding vegetable crops . Westport, Connecticut: Avi, 1986. p.209-242. 584p.

WILSON, H.D., DOEBLEY, J., DUVALL, M. Chloroplast DNA diversity among wild and cultivated members of Cucurbita (Cucurbitaceae). Theor Appl Genet, v.84, p.859-865, 1992. 